\title{
Citrus TISSUE CULTURE WITH TWO DIFFERENT APPROACHES
}

\author{
Firoozeh Chamandoosti* \\ Iranian Research Institute of Plant Protection, Agricultural Research, Education and Extension \\ Organization (AREEO), Tehran, Iran \\ $\mathrm{PhD}$ of Cellular and Developmental Biology, Assistant Professor of Iranian Research Institute of \\ Plant Protection, Department of Plant Diseases \\ *Corresponding author: fychamandoosti@yahoo.com
}

\begin{abstract}
Citrus is an important genius for economy and human health but a susceptible genius against biotic and abiotic stresses, so it needs to improved programs. Different basal media (MS, $1 / 2 \mathrm{MA}, 1 / 3 \mathrm{MS}$ and DKW) and different kind and concentrations of plant growth regulators i.e. BA, KIN, 2ip, ZE and TDZ $(0-2 \mathrm{mg} / \mathrm{l})$ and NAA, IAA and IBA $(0-2 \mathrm{mg} / \mathrm{l})$ added with 30 $\mathrm{g} / \mathrm{l}$ sucrose, $3 \mathrm{~g} / \mathrm{l}$ active charcoal and $7.5 \mathrm{~g} / \mathrm{l}$ bacteriological agar] were used for organogenesis include shooting and rooting, also callusing from nodal explant of Citrus latifolia. MS medium supplemented with $1 \mathrm{mg} / \mathrm{l} \mathrm{BA}$, and $0.01 \mathrm{mg} / \mathrm{l} \mathrm{NAA}$ is the best media for multiple shoot induction on nodal explants and elongation of them. Other cytokinins had not significant effects on shoot induction and multiplication. Using of $0.01 \mathrm{mg} / \mathrm{IBA}$ instead of $0.01 \mathrm{mg} / \mathrm{l}$ NAA on medium with $1 \mathrm{mg} / \mathrm{l} \mathrm{BA}$, led to multiple shoot induction on nodal explant indirectly. Rooting was induced on DKW medium plus $1.5 \mathrm{mg} / \mathrm{l} \mathrm{NAA}$ in the best way compared another media. Both direct and indirect organogenesis (multiple shoot induction) were carried out on media with very similar contents. So we can use very simple and practical methods tissue culture for different improved programs in Citrus genius genius.
\end{abstract}

Keywords: Citrus latifolia, direct organogenesis, indirect organogenesis, micropropagation

\section{INTRODUCTION}

Citrus fruits are one of the most important and the most economic fruits in Iran alike all over the world. They are very desirable duo to their very good pleasant aroma and taste also due to their role in nutritional benefits and human health. Citrus fruits contain a variety of vitamins, minerals, fiber, and phytochemicals such as carotenoids, flavonoids, and limonoids, which appear to have biological activities and health benefits. There is considerable evidence that Citrus fruit have antioxidant and antimutagenic properties and positive associations with bone, cardiovascular, and immune system health (Codoner - French and Valls - Belles 2010).

Citrus cultivation affects by many biotic and abiotic stresses. For example Witches Broom Disease of Lime (WBDL) as a biotic stress is a serious disease for some Citrus species if not controlled. WBDL that its agent is "Candidatus Phytoplasma aurantifolia" has been reported from Iran since 2000 (Bove et al., 2000). Application of tolerant and resistant rootstocks and 
varieties is the best way to overcome some plant diseases such as WBDL especially by using micropropagation that is an alternative method of vegetative propagation. It offers many unique advantages over conventional propagation methods such as rapid multiplication of valuable genotypes, expeditious release of improved varieties, production of disease - free quality planting materials, non - seasonal production (round the year), higher yield, earlier and more vigorous sucker production, uniform and mass production in relatively short periods of time, germplasm conservation and facilitating their easy international exchange (Datta et al., 2017). Also genetic manipulation facilitates rapid plant improvement, compared to conventional breeding methods, especially in cases where changes through the addition of one or more genes are necessary, while preserving cultivar integrity (Dutt et al., 2011).

Micropropagation is a method to produce genetically identical plantlets by using tissue culture techniques (Chieri, 2001). On the other hand tissue culture and micropropagation are an essential prerequisite for genetic manipulation.

According to the mentioned above and emphasize to direct and indirect role of tissue culture in plant improvement programs (micropropagation and genetic manipulation respectively), using of tissue culture methods for Citrus genius genius is very imperative. In this research plantlet regeneration using nodal explant and two different form of organogenesis (direct and indirect) was studied in one of the most important species of Citrus named Citrus latifolia. It is necessary to mention that two different form of organogenesis (with or without callusing phase) was done with very small changes in content of media.

\section{MATERIALS AND METHODS}

\section{Preparation of plant materials and establishment of explants}

One year old scions of Citrus latifolia were prepared from Jahrom, Fars province, Iran. Shoots with $12-15 \mathrm{~cm}$ length were used as explant. This manner for preparing explant (using shoots with $12-15 \mathrm{~cm}$ length was done in the second and the third years of establishment of scions in greenhouse).

After transferring of shoots measuring $12-15 \mathrm{~cm}$ length from greenhouse to laboratory and defoliating of them, shoots were cut to segment measuring $7-8 \mathrm{~mm}$ with one node. Segments were sterilized with $25 \%$ commercial hypochlorite sodium for $50 \mathrm{~min}$ then were rinsed in sterile distilled water $4-5$ times. Explants were culture on MS (Murashige and Skoog 1962) media without any plant growth regulators.

\section{Shoot induction and multiplication}


MS medium supplemented with 0.01 $2 \mathrm{mg} / \mathrm{l}$ cytokinins consist of BA, KIN, 2iP, ZE and TDZ and $0.01-2 \mathrm{mg} / \mathrm{l}$ auxins consist of NAA and IBA plus 3\% sucrose and $0.75 \%$ bacteriological agar were tested for shoot and multiplication. All of media were adjusted to $\mathrm{pH} 5.8$ then were autoclaved at $120^{\circ} \mathrm{C}$. Media distributed in petri dishes measuring $9 \mathrm{~cm}$. Each petri dish contained 9 explants with 4 replicates. The mean number of regenerated shoots and the height of them were recorded after one month.

\section{Elongation of regenerated shoots}

When height of regenerated shoots reached to $1 \mathrm{~cm}$, subculturing of them were acted. For subculturing, media were used consist of different combinations of $0-2 \mathrm{mg} / \mathrm{l}$ $\mathrm{KIN}, \mathrm{GA}_{3}, \mathrm{BA}, \mathrm{NAA}$ and IAA.

Root induction at the base of regenerated shoots and whole plantlets regeneration

MS, $1 / 2 \mathrm{MS}$ and $1 / 3 \mathrm{MS}$ and DKW

(Driver and Kuniyuki 1984) media with $0-2$ $\mathrm{mg} / \mathrm{l}$ auxins such as NAA, IBA and IAA were used for rooting at the base of regenerated shoots with sufficient growth $(1-1.5 \mathrm{~cm})$.

\section{Adaptation of plantlets to natural environment}

Whole plantlets resulted from rooting of regenerated shoots, were taken out of glass media and were washed with running tap water for erasing of agar around the roots then plant out in clear disposable glass consist of sterilized soil and perlite (1:1). For moisture retention of plantlets the opening of the pots (clear disposable glass) were covered with another clear disposable glass.

\section{Experimental design and data analysis}

Experiments were set up in a completely randomized design and the means (the mean number and the mean height of regenerated shoots and roots) were compared with Duncan Multiple Range Test. Data were subjected to \pm SD.

\section{RESULTS AND DISCUSSION}

Effect of different types of cytokinins and auxins on shoot induction and multiplication

Direct and indirect organogenesis (shoot formation) was accomplished in two forms, in the sense that the regenerated shoots with different length, number and morphological appearances were propagated on nodal explants. This difference related to cytokinin type at first. The effect of BAP compared to other cytokinins was incomparable [Fig 1. $\left(\mathrm{a}_{1}-\mathrm{a}_{2}\right)$ ]. On MS media supplemented with $0.01-2 \mathrm{mg} / \mathrm{l} \mathrm{BAP}$ at least 2 and maximum 8 regenerated shoots were sprouted from the single node of explants in the event that the number of regenerated shoots on MS medium with $0.01-2 \mathrm{mg} / \mathrm{l}$ other cytokinins such as KIN, ZE, 2ip and TDZ was 2 maximum [Fig 1. $b_{1}-b_{4}$ )]. Also the regenerated shoots on MS medium with different concentration of BAP were big, and have $2-3$ leaves with grown leaf blade but the regenerated micro shoots on MS medium 
with different concentrations $(0.01-2 \mathrm{mg} / \mathrm{l})$ of said cytokinins were very small with very small leaves blade. Positive and potent effect of BAP on shoot induction is in agreement with reports of other researchers. What is important in the report of these researchers is that the positive effect of BAP on shooting in plant tissue culture includes, plants belonging to different families. For example [Cucurbita maxima Duch (Cucurbitaceae) (Lee et al., 2003)], [Ruta graveolunse L. (Rutaceae) (Ahmad et al., 2010)], [(Lycopersicon esculentum L. (Solanaceae) (Rai et al., 2012)], and [Japanese pear (Rosaceae) (Kadota et al., 2001)].

Also how to use of cytokinin, solely and or plus other plant growth regulators was affective on shoot induction and status of it, so that on MS media with different concentrations of BAP increasing of BAP concentration led to increasing of the number of regenerated shoots (5.5 per explants on MS medium plus $2 \mathrm{mg} / \mathrm{l} \mathrm{BAP}$ ). But on MS media supplemented with different concentrations of BAP and $0.01 \mathrm{mg} / \mathrm{l} \mathrm{NAA}$ increasing of BAP concentration led to decreasing of the number of regenerated shoots. So the maximum number of regenerated shoots resulted on MS medium with $1 \mathrm{mg} / 1 \mathrm{BAP}$ and $0.01 \mathrm{mg} / 1 \mathrm{NAA}$ (6.2 per explants) (Table 1). There are reports either similar our result or contradictory our result. In Chlorophytum borivilianum the increasing of BAP concentration $(2-3 \mathrm{mg} / \mathrm{l})$ had significantly positive effect on shoot multiplication (Mehdi Farshad et al., 2014). But in Citrus lemon L. cv. Kaghzi Kalan with increasing of BAP concentration shoot proliferation decreased (Komal et al., 2013).

In addition of cytokinin types, auxin type influenced on the form of shoot initiation, also. As mentioned above due to the very good effect of BAP on shoot induction and multiplication of regenerated shoots, we focused on continuing of experiments using BAP. The continuing of experiments showed that how to use the BAP solely or with other plant growth regulators such as NAA, was affective on shoot induction and different form of it, also. What it seems in the first moment is, there is not any difference between media with different concentrations of BAP and NAA and different concentrations of BAP and IBA. As it can be seen the maximum number of regenerated shoots on media with similar proportion of cytokinin and auxin but different kind of them is equal. But there is an important difference between two media. On MS medium with $0.01-2 \mathrm{mg} / \mathrm{l} \mathrm{BAP}$ and $0.01 \mathrm{mg} / \mathrm{l} \mathrm{IBA}$, callus induction on nodal explant in the place of nods were initiated at first then after $2-3$ weeks with differentiation of calli cells to initial forms of vegetative meristem, and appearance of the initial forms of leaves from this meristem, indirect organogenesis was done [Fig 1. $\left(\mathrm{c}_{1}-\right.$ 
$\left.\mathrm{c}_{4}\right)$ ]. Therefore with an inappreciable alternation in content of media direct organogenesis was altered indirect organogenesis. In another plant from Citrus genius, Sweet orange (Citrus sinensis L.), an inappreciable alternation in plant taxonomy or in fact genetic characteristics of plants (Navelina sweet orange variety and genetically close variety of it namely Pineapple sweet orange variety) using $3 \mathrm{mg} / \mathrm{l}$ BAP led to different results. $3 \mathrm{mg} / \mathrm{l} \mathrm{BAP}$ led to efficient shoot organogenesis in Pineapple but not in Navelina. Furthermore different effects were observed when the auxin NAA was added to BAP - containing regeneration media. Although NAA addition at $0.5 \mathrm{mg} / \mathrm{l}$ enhanced cambial callus formation, number of shoots and their elongation in Navelina, the contrary effect was observed in Pineapple (Rodeiguez et al., 2008). It is clear that the reason of these observations is complex interactions between plants with different genetic characteristics and the effect of plant growth regulators.

\section{Elongation of regenerated shoots Length of regenerated shoots on induction media}

In some induction media the length of regenerated shoots reached the approximately $4 \mathrm{~cm}$ (Fig 1.d $\mathrm{d}_{1}$ ). However for attaining more growth of regenerated shoots, we sub cultured of them on media with new composition (Table 2). As it is perceived sub culturing of shoots on new media did not lead remarkable result and longitudinal growth of shoot was very low and caused of weakness and wanes of shoots (on media containing $\mathrm{GA}_{3}$ ) . Our conclusion about effect of $\mathrm{GA}_{3}$ for longitudinal growth have been proved by other researchers (Perez - Tornero et al., 2009). In some cases duo to beneficial influence of active charcoal in tissue culture (micropropagation, orchid seed germination, somatic embryogenesis, anther culture, synthetic seed production, protoplast culture, rooting, bulb formation especially stem elongation) (Denis Thomas, 2008)., recently mentioned substance was added to media, but, no considerable result was obtained. Despite of many positive effects, negative effects have been reported about active charcoal in tissue culture. For example microspore embryogenesis in Brassica oleraceae (Da Silva and Dias 1999), embryogenic callus in Phoenix camariensis (Huong et al., 1999) and micropropagation in Gymnema sylvestre (Komalavalli and Rao 2000). One of the most acceptable reason, for these observations is concentration of active charcoal from a range of $0.002 \mathrm{~g} / \mathrm{l}$ to $150 \mathrm{~g} / \mathrm{l}$ differed wildly in plant tissue culture ${ }^{18}$. It is usually stated that the rooting of little shoots especially in Citrus genius is very weak and so an intermediate phase is necessary and so the difficulty of rooting is still one of the major obstacles to successful micropropagation (Samaan et al., 2014). According to results of this research 
not only the little shoots have potential of rooting but also subculturing of them on media for elongation is not necessary and regenerated shoots on induction media grew successfully [Fig 1. $\left.\mathrm{d}_{2}-\mathrm{d}_{4}\right)$ ].

The results of rooting experiments showed that, two important factors led to root induction that were, increased concentration of exogenous auxin and decreased concentration of media salts.

On full - strength MS and DKW media, high auxin (NAA) concentration promoted in vitro rooting. Successful rooting numbering $3-4$ on the base of each regenerated shoot was observed $2-3$ weeks after culturing on above mention media. The roots were white and potent also and the mean length of them reached to $3 \mathrm{~cm}$ in the best condition in terms of the content of media (Fig 1. e).

Another successful medium for rooting, were media with decreased concentrations MS salt ( $1 / 2 \mathrm{MS}$ and $1 / 3 \mathrm{MS})$ supplemented with IBA and IAA (Table 3). On these media rooting was occurred after 4 weeks approximately. The roots were thick and yellowish and numbering $2-3$, but were unavailing (for plantlet production) because connection and cohesion, and the other hand vascular relation of them was very loose with the base of regenerated shoot so the most of them were cut during the transfer of plantlets

from culture glasses. So it is observed that auxin is necessary for rooting according to results of this research. There are many reports that show, auxin is necessary for Citrus rooting. According to Katsias and Roussos (Kotsias and Koussos 2001). Dipping the base of the explants in a $50 \%$ ethanol solution of IBA at $1000 \mathrm{mg} 1$ for $5 \mathrm{~s}$ resulted in $80 \%$ rooting with subsequent $90 \%$ survival of these explants, during acclimatization under mist.

In two sweet orange (Citrus sinensis L. Osb), pineapple and pera root formation and development decreased in both sweet orange cultivars concomitant with the reduction of medium strength. The $\alpha$-naphtaleneacetic acid was important during the root differentiation phase, but its combination with indole-3-butyric acid was essential for root elongation (Mendes et al., 2011). Also in Citrus sinensis L. Local Cv. effect of auxins and auxins like substance (IBA, NAA, IAA, 2, 4-D and 2, 4, 5-T) and type of cutting on rooting ability of orange cuttings were tested. The results showed that the overall rooting responses was higher in the treatment with IBA and NAA rather than with IAA, 2,4-D and 2,4,5-T (Khursheed and Salih 2007). 
Table 1. Effect of MS media and different concentrations of plant growth regulators on regenerated shoots (number and length) on explants of Citrus latifolia

\begin{tabular}{|c|c|c|c|c|c|}
\hline Media & $\begin{array}{c}\mathrm{BA} \\
\mathrm{mg} / \mathrm{l}\end{array}$ & $\begin{array}{l}\text { NAA } \\
\text { mg/l }\end{array}$ & $\begin{array}{l}\text { IBA } \\
\mathrm{mg} / \mathrm{l}\end{array}$ & $\begin{array}{c}\text { The mean number } \\
\text { of regenerated } \\
\text { shoots }\end{array}$ & $\begin{array}{c}\text { The mean length } \\
\text { of regenerated } \\
\text { shoots }(\mathrm{cm})\end{array}$ \\
\hline $\mathbf{M}_{1}$ & 2 & 0 & 0 & $2.66 \pm 093^{\mathrm{abc}}$ & $4.7 \pm 3.1^{\mathrm{d}}$ \\
\hline $\mathbf{M}_{2}$ & 1 & 0 & 0 & $1.8 \pm 0.52^{\mathrm{abc}}$ & $8.2 \pm 5.5^{\mathrm{ab}}$ \\
\hline $\mathbf{M}_{3}$ & 0.1 & 0 & 0 & $1.8 \pm 0.61^{\mathrm{abc}}$ & $7.75 \pm 4.5^{\mathrm{bc}}$ \\
\hline $\mathbf{M}_{4}$ & 0.01 & 0 & 0 & $1.2 \pm 0.44^{\mathrm{bc}}$ & $2 \pm 0.01^{\mathrm{ef}}$ \\
\hline $\mathbf{M}_{5}$ & 2 & 0.01 & 0 & $2.2 \pm 0.85^{\mathrm{abc}}$ & $1.37 \pm 0.54^{\mathrm{f}}$ \\
\hline $\mathbf{M}_{6}$ & 1 & 0.01 & 0 & $3.2 \pm 0.12^{\mathrm{a}}$ & $5.52 .2^{\mathrm{cd}}$ \\
\hline $\mathbf{M}_{7}$ & 0.1 & 0.01 & 0 & $0.8 \pm 0.55^{\mathrm{c}}$ & $1.75 \pm 0.97^{\mathrm{f}}$ \\
\hline $\mathbf{M}_{8}$ & 0.01 & 0.01 & 0 & $0.8 \pm 0.47^{\mathrm{c}}$ & $4.25 \pm 1.2^{\mathrm{de}}$ \\
\hline M9 & 2 & 0 & 0.01 & $1.5 \pm 0.90^{\mathrm{abc}}$ & $1.42 \pm 0.99^{\mathrm{abc}}$ \\
\hline $\mathbf{M}_{10}$ & 1 & 0 & 0.01 & $2.5 \pm 1.01^{\mathrm{ab}}$ & $1.84 \pm 0.99^{\mathrm{abc}}$ \\
\hline $\mathbf{M}_{11}$ & 0.1 & 0 & 0.01 & $1.4 \pm 0.77^{\mathrm{abc}}$ & $4.39 \pm 3.5^{\mathrm{ab}}$ \\
\hline $\mathbf{M S}_{12}$ & 0.01 & 0 & 0.01 & $1.2 \pm 0.99^{\mathrm{bc}}$ & $3.29 \pm 2.2^{\mathrm{bc}}$ \\
\hline
\end{tabular}

Mean followed by same letter(s) are not significantly different based on Duncan's at the 0.05 probability level.

As it mentioned in material and abiotic stresses), establishment of tissue method section after transferring of plantlets culture plan by direct organogenesis that lead form glass culture to little pot with mixture of to preservation of desirable genetic soil and perlite (1:1) and gradual adaptation of characteristic of species is instrumental. And them, 30\% could survive and grew slow (Fig for gene transfer aims in order to genetic 1. f).

The most important result of this study modification of plants, callus as a less differentiated tissue and proper for gene is that was both direct and indirect transfer is essential. Although all of plant organogenesis in Citrus latifolia was very interesting and very useful for us. It is clear that in improvement programs of Citrus both type of organogenesis is necessary. For resistant or tolerant species (against biotic and tissues without cell wall and meristemtic cell can used as purpose in gene transfer plan. On the other hand somaclonal variation that is the variation seen in plants that have been produced by plant tissue culture. 
Chromosomal rearrangements are an variation can lead to new cultivars (e.g., important source of this variation. Somaclonal disease resistance, new leave pattern) that variation is not restricted to, but is particularly may have desirable ornamental characteristics common in, plants regenerated from callus or increased pest resistance (Saurabh and (Patricia et al., 2004) and (Saurabh and Sharma 2015).

Sharma 2015). In some cases, somaclonal

Table 2. Effect of different basal media and different concentrations of plant growth regulators on elongation of regenerated shoots of Citrus latifolia

\begin{tabular}{|c|c|c|c|c|c|c|c|}
\hline MEDIA & $\begin{array}{l}\text { AC } \\
\text { MG/L }\end{array}$ & $\begin{array}{l}\text { NAA } \\
\text { MG/L }\end{array}$ & $\begin{array}{l}\text { IBA } \\
\text { MG/L }\end{array}$ & $\begin{array}{l}\text { IAA } \\
\text { MG/L }\end{array}$ & $\begin{array}{l}\text { GA3 } \\
\text { MG/L }\end{array}$ & $\begin{array}{l}\text { BA } \\
\text { MG/L }\end{array}$ & $\begin{array}{l}\text { ELONGATION } \\
\text { OF } \\
\text { REGENERATED } \\
\text { SHOOTS }\end{array}$ \\
\hline $\mathbf{M S}_{1}$ & 3000 & 0 & 0 & 0 & 0 & 0 & $x$ \\
\hline $\begin{array}{l}\mathbf{M S}_{2} \\
(1 / 2 \mathrm{MS})\end{array}$ & 3000 & 0 & 0 & 0 & 0 & 0 & $x$ \\
\hline $\mathbf{M S}_{3}$ & 0 & 0 & 0 & 0.01 & 1 & 0 & - \\
\hline $\mathbf{M S}_{4}$ & 0 & 0 & 0 & 1 & 0.01 & 0 & - \\
\hline $\mathbf{M S}_{5}$ & 0 & 0 & 0.1 & 0 & 1 & 1 & - \\
\hline $\mathbf{M S}_{6}$ & 0 & 0 & 1 & 0 & 0.1 & 1 & - \\
\hline $\mathbf{M S}_{7}$ & 0 & 0.01 & 0 & 0 & 1 & 1 & $x+$ \\
\hline $\mathbf{M S}_{8}$ & 0 & 0.01 & 0 & 0 & 0.1 & 1 & - \\
\hline $\mathbf{M S}_{9}$ & 0 & 2 & 0 & 0 & 0 & 1 & - \\
\hline $\mathbf{M S}_{10}$ & 0 & 0 & 2 & 0 & 0 & 1 & - \\
\hline
\end{tabular}

+: plenty $\quad \times$ : moderate $\quad-:$ insignificant 
Table 3. Effect of different basal media and different concentrations of plant growth regulators on root induction in the base of regenerated shoots of Citrus latifolia.

\begin{tabular}{c|ccccc}
\hline MEDIA & NAA & \multicolumn{1}{l}{ IBA } & \multicolumn{1}{c}{ IAA } & \multicolumn{1}{l}{ BA } & \% ROOTING \\
& MG/L & MG/L & MG/L & MG/L & \\
\hline MS & 1.5 & 0 & 0 & 0 & 75 \\
MS & 0 & 1.5 & 0 & 0 & 0.2 \\
MS & 2 & 0 & 0 & 1 & 16 \\
MS & 0 & 2 & 0 & 0 & 3 \\
MS & 0 & 2 & 0 & 1 & 2.5 \\
MS & 1 & 0 & 0 & 0 & 34 \\
MS & 0 & 1 & 0 & 0 & 0.01 \\
$1 / 2 M S$ & 1 & 1 & 0.1 & 0 & 0.5 \\
$1 / 2 M S$ & 0 & 1 & 0.1 & 0 & 28 \\
$1 / 3$ MS & 1 & 1 & 0.1 & 0 & 45 \\
$1 / 3$ MS & 0 & 1 & 0.1 & 0 & 69 \\
DKW & 1.5 & 0 & 0 & 0 & 97 \\
\hline
\end{tabular}

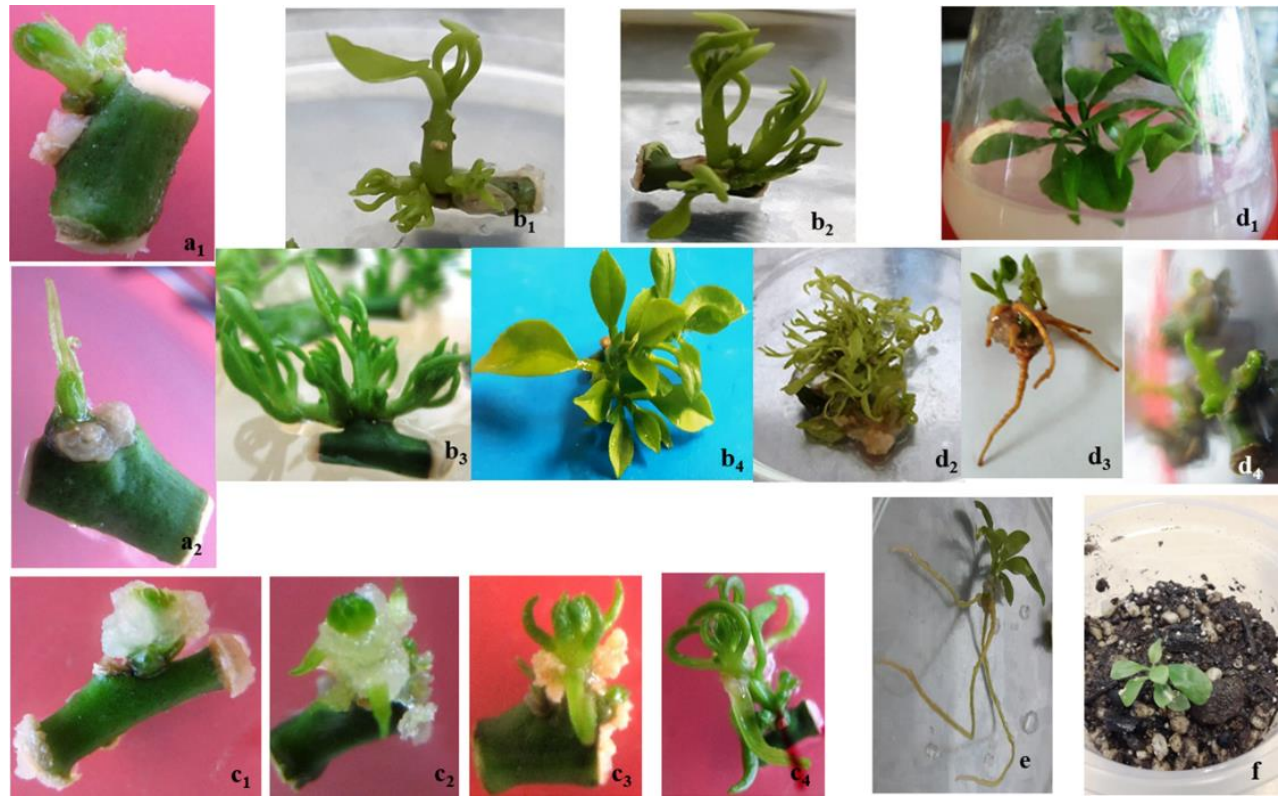

Fig.1. In vitro direct and in direct organogenesis from nodal explants of Citrus latifolia. Nodal explants were cultured on MS medium supplemented with $\mathrm{a}_{1:} 1 \mathrm{mg} / \mathrm{l} \mathrm{BA}+0.01 \mathrm{mg} / \mathrm{l} \mathrm{NAA}$ and $\mathrm{a}_{2}: 1 \mathrm{mg} / \mathrm{l} \mathrm{TDZ}+0.01 \mathrm{mg} / \mathrm{l} \mathrm{NAA} . \mathrm{b}_{1}-\mathrm{b}_{4}-$ Multiple shoot induction on nodal explants on MS medium with $1 \mathrm{mg} / \mathrm{l} \mathrm{BA}+0.01 \mathrm{mg} / \mathrm{l} \mathrm{NAA} . \mathrm{c}_{1}-\mathrm{c}_{4}$. Indirect shoot induction on nodal explants on MS medium with $1 \mathrm{mg} / \mathrm{l} \mathrm{BA}+0.01 \mathrm{mg} / \mathrm{l} \mathrm{IBA} . \mathrm{d}_{1}-\mathrm{d}_{4}$. Effect of different basal media supplemented with different plant growth regulators and $0.3 \%$ active charcoal on elongation of regenerated shoots. e. root induction on the base of regenerated shoots in DKW medium plus $1.5 \mathrm{mg} / \mathrm{l} \mathrm{NAA}$ and whole plantlet formation. $\mathrm{f}$. adapted plantlets, growing up and new leaf formation. 


\section{CONCLUSION}

In Citrus latifolia direct and indirect organogenesis is possible, utilize different media and minor manipulations in their content. This possibility lead to use different tissue culture methods for different improved programs in important genius, Citrus, as micropropagation, somaclonal variation and preparation of suitable tissue for gene transfer programs (biotechnology).

\section{REFERENCES}

Ahmad, N., Faisal, M., Anis, M., \& Aref, I.M. (2010). In Vitro callus induction and plant regeneration from leaf explants of Ruta graveolense L. South African Journal, 76(3), 597 - 600.

Bove, J. J.L. K. Danet, K. Bananej, k. \& Hassanzadeh, N. (2000). Witches Broom Diseases in Iran. Fourteenth IOCV Conferences, Insect Transmitted Procaryotes, pp. 207 212.

Chieri, K. (2001). Concepts and Background of Photoautotrophic Micropropagation. Progress in Biotechnology, 18, $325-334$. doi: 10.1016/S0921-0423(01)800897.

Codoner - Franch, P., \& Valls - Belles, V. (2010). Citrus as Functional foods. Current Topics in Nutraceutical Research, 8 (4), 173 - 184.

Datta, S.K, Chakraborty, D., \& Janakirma, T. (2017). Low Cost Tissue Culture. Journal of Plant Science Research, 33(2), 181 - 199.

Da Silva Dias, J. C. (1999). Effect of activated charcoal on Brassica oleracea microspore culture embryogenesis. Euphytica, 108, 65 - 69.doi: https://doi.org/10.1023/A:10036340 30835 .
Dennis Thomas, T. (2008). The role of activated charcoal in plant tissue culture. Biotechnology advances, 26, 618 631.doi: 10.1016/j.biotechadv.2008. 08.003 .

Driver, J.A, \& Kuniyuki, A.H. 1984. In vitro propagation of Paradox walnut Juglans hindsii $\times$ Juglans regia rootstock. HortScience, 19, 507 509.

Dutt, M., Vasconellos, M., \& Grosser, JW. (2011). Effects of antioxidants on Agrobacterium - mediated transformation and accelerated production of transgenic plants of Mexican lime (Citrus aurantifolia Swingle). Plant Cell Tissue and Organ culture, 107, 79 - 89. doi: https://doi.org/10.1007/s11240-0119959-x.

Huong, L.T.L., Baiocco, M., Huy, B.P., Mezzetti, B., Santilocchi, R., \& Rosati, P. (1999). Somatic embryogenesis in Canary Island date palm. Plant Cell Tissue and Organ Culture, 56, 1 - 7 . doi: https://doi.org/10.1023/A:10062318 32555.

Kadota, M., Lmizu, K., \& Hirano, T. (2001). Double - phase in vitro culture using sorbitol increases shoot proliferation and reduces hyperhydricity in Japanese pear. Scientica Horticulturae, 89(3), $207-215$. https://doi.org/10.1016/S03044238(00)00234-X.

Khursheed, M.Q., J.R. Salih. (2007) Effect of different auxin and type of cutting on rooting ability of orange (Citrus sinensis L. Local Cv.) cuttings. Journal of pure and applied Science. 19(2): 103 - 110 .

Komal, G., Sharma, R., Singh, P.K., \& Govind, S. (2013). Micropropagation of seedless lemon (Citrus limon L. cv. Kaghzi Kalan) and assessment of genetic fidelity of micropropagated plants using RAPD markers. 
Physiology and Molecular Biology of Plants, 19(1), $137-145$. doi: 10.1007/s12298-012-0148-0.

Komalavalli, N., \& Rao, M.V. (2000). In vitro micropropagation of Gymnema sylvestre a multipurpose medicinal plant. Plant Cell Tissue and Organ Culture, 61, 97 - 105. doi: https://doi.org/10.1023/A:10064212 28598.

Kotsias, D., \& Roussos, P.A. (2001). An investigation on the effect of different plant growth regulating compounds in in vitro shoot tip and node culture of lemon seedlings. Scientica HortiCulture, 89, $115-128$. https://doi.org/10.1016/S03044238(00)00227-2.

Lee, Y.K., W. Chung, W., \& Hiroshi, E. (2003). Efficient plant regeneration via organogenesis in winter squash (Cucurbita maxima Duch.). Plant Science, $164,413-418$. https://doi.org/10.1016/S01689452(02)00429-6.

Mehdi Farshad, A., Maheran, A.A., Nurashikin, K. \& Ismanizan, I. (2014). Effect of cytokinin types, concentrations and their interactions on in vitro shoot regeneration of Chlorophytum borivilianum Sant. \& Fernandez. Electronic Journal of Biotechnology, 17, $275-279$. https://doi.org/10.1016/j.ejbt.2014.0 8.004.

Mendes, A.F.S., Cidade, L.C., Otoni, W.C., Soares - Filho W.S., \&. Costa, M.G.C. (2011) Role of auxin, polyamines and ethylene in root formation and growth in sweet orange. Biological Plantarum, 55(2), 375

378.

https://doi.org/10.1007/s10535-0110058-y.

Murashige, T., \& Skoog, F. (1962). A revised medium for rapid growth and bioassays with tobacco tissue cultures. Phyiol. Plant, 15, 473 - 497. https://doi.org/10.1111/j.1399-

3054.1962.tb08052.x.

Patricia, N., Bordallo, P.N, Silva, D.H., Maria, J. Cosme, D.C. \& Fontes, E. P. (2004).Somaclonal variation on in vitro callus culture potato cultivars. Horticultura Brasileira, 22(2), $300-$ 304. https://doi.org/10.1590/S010205362004000200027.

Perez - Tornero, O., Tallon, C.I. \& I. Porras, I. (2009). An efficient protocol for micropropagation of lemon (Citrus limon) from mature nodal segments. Plant Cell Tissue and Organ Culture, 100, $263-271$. doi: https://doi.org/10.1007/s11240-0099643-6.

Rai, G.K., Rai, N.P., Kumar, S., Yadav, A., \& Rathaur, S. (2012). Effects of explant age, germination medium, pre - culture parameters, inoculation medium, $\mathrm{pH}$, washing medium, and selection regime on Agrobacterium mediated transformation of tomato. In Vitro Cellular and Developmental Biology, 48, 565 - 578. doi: https://doi.org/10.1007/s11627-0129442-3.

Rodeiguez, A., Cervera, M., Enric Peris, J., \& Pena, L. (2008). The same treatment for transgenic shoot regeneration elicits the opposite effect in mature explants from two closely related sweet orange (Citrus sinensis (L.) Osb.) genotypes. Plant Cell, Tissue and Organ culture, 93, 97 - 106. doi: https://doi.org/10.1007/s11240-0089347-3.

Samaan, L.G., EL - Kady, M.I. Shalan, A.M., \& Mohamed. M.M. (2014) Biological factor to optimize rooting and shoot multiplication on micro cutting of volkamer lemon (Citrus volkameriana Ten.) rootstocks. Journal of Plant Protection, 5(2), 325 346. http://www.researchgate.net/publicat ion/315654731. 
Saurabh, B., \& Sharma, K. (2015). Modern applications of plant biotechnology in pharmaceutical sciences. (pp. $394-$ 404). Academic Press. doi: http://doi.org/10.1016/C2014-002123-5 . 